\title{
Remaking the Bible: English Reformation Spiritual Conduct Books
}

HELAINE

RAZOVSKY

Summary: Among the thousands of devotional works produced in the centuries following the English Reformation are hundreds that may be called spiritual conduct books. This article defines the term "spiritual conduct book" on the basis of a text's purpose and audience. Unlike more familiar secular conduct books, such as Castiglione's Book of the Courtier, spiritual conduct books place success in the next world above success in this world. This group of books, although derived from the Bible and from biblical commentary, also reflects secular interests, including class conflicts.

$\mathrm{T}^{1}$ an introduction to John Bunyan's Pilgrim's Progress, N. H. Keeble Iwrites: "The classics of Puritan spirituality are predominantly autobiographical. ...."2 During the English Renaissance, however, a more popular form of Protestant (Puritan and non-Puritan) text is a type of conduct book, the spiritual conduct book, associated in its development with the proliferation of biblical commentaries engendered by the Reformation. All of these books are related in greater or lesser ways to the Bible, the text placed at the center of the Reformation by the reformers of both church and self. Like biblical commentary, like spiritual autobiography, the spiritual conduct book responds to the Bible, and so its characteristics are shaped by that response. The titles of some of these books suggest one of their crucial characteristics: their focus on the Bible as the arbiter of conduct: William Gouge's The Whole-Armor of God, or The Spiritval Fvrnitvre which God hath provided to keepe safe euery CHRISTIAN SOVLDIER from all assaults of Satan (1616) is a wonderful example of how the Bible itself, in this case some verses from Ephesians, apparently suggested to reformers its own efficacy in prescribing conduct. 
The spiritual conduct book has never been distinguished clearly from other types of conduct books, in part, I believe, because it is a product of the Reformation rather than of the Renaissance. This essay will address three issues related to the spiritual conduct book. First, it will outline the characteristics of the English spiritual conduct book in opposition to those of the more widely known secular conduct books, the courtesy books, of the Renaissance. Next, it will explain the probable development of the spiritual conduct book as an offshoot of biblical commentary. Finally, it will illustrate a few of the particular ways in which the spiritual conduct book remakes the Bible as an aid to personal reformation. This process will shed light not only on spiritual conduct books themselves, but also on how a genre develops. In turn, the development of this genre will also offer some insights into the relation between class dynamics and the prescription of conduct.

The Protestant Reformation in England produced many variants on the Bible. Some are quite obvious in their design. For example, in 1629 , Simon Wastell, a schoolmaster, published a book called Microbiblion, or, the Bibles Epitome. Although its title may seem modern, the book is one of numerous English Reformation texts that remake the Bible. (By "English Reformation texts," I mean here texts produced between 1534, the beginning of the English Reformation, and the restoration of the monarchy in 1660.) In this example, Wastell has rewritten the Bible in verse; the first letter of each verse composes at least one complete alphabet (" $A$ " through "V," excluding "J") for each book of the Bible. ${ }^{3}$ Remaking the Bible is a common Reformation activity; the New Cambridge Bibliography of English Literature lists more than 20 epitomes (summaries) and harmonies (collection of parallel biblical passages with commentary), and it is far from exhaustive. ${ }^{4}$ Published writers were not the only ones who produced personal visions of the Bible; everyone was encouraged to create his or her own hand-tailored "microbiblion." In Directions for the Private Reading of the Scriptures (1618), the preacher Nicholas Byfield gives the following directions for assembling and storing pertinent passages:

First make thee a little paper booke of a sheete or two of paper, as may be most portable: then write vpon the toppe of euery leafe the title for that that thou wouldest obserue in reading. Chuse out only six or eight titles out of the whole number of such as for the present thou hast most neede to obserue: or onely so many as thou art sure thy memory will easily cary to thy reading, whether more or fewer. ${ }^{5}$

Not surprisingly, reformers' insistence on the individual Protestant's duty to interpret the Bible often led interpreters to rewrite or remake biblical 
texts as a way of encouraging or shaping interpretation by another. Remaking the Bible produces what amount to alternative biblical texts and commentary on the original text (activities that sometimes merge). This remaking of the Bible generated many types of documents, from paraphrases to commentaries; one type is the English Reformation spiritual conduct book. The ways in which these spiritual conduct books remake the Bible differ. Some authors of spiritual conduct books collect abstracts from various books of the Bible and construct from them books for specialized audiences on specialized conduct. Others seem to imitate or echo the methods of writers of books of the Bible, producing what we might call a new apocrypha.

In all cases, the relation between Bible and spiritual conduct book results in an intertwining of texts that might be called a hypertext. Although the word "hypertext" was coined to describe a computer-based text retrieval system, the status of a written text is also magnified by a web of commentary, as is the case with the Hebrew Talmud or elaborate Christian Bibles that offer commentary, definitions, and maps. In spiritual conduct books, biblical text is reproduced and often rewritten, and references to biblical and other texts often appear in the margins. Commentary on the text always includes prescriptions for conduct based on an interpretation of the biblical text that may or may not be stated explicitly. But before delving more deeply into the nature of these spiritual conduct books and how they respond to the Bible, we need to define them.

\section{Defining the Spiritual Conduct Book}

Defining the spiritual conduct book requires us to distinguish it from other kinds of conduct books, including the most commonly known, courtesy books, such as Baldassarre Castiglione's Book of the Courtier (1528), which prescribe conduct for an aristocratic audience. Scholars have not agreed on standard definitions for the terms "courtesy book" and "conduct book." Some scholars, such as Louis B. Wright in Middle-Class Culture in Elizabethan England (1935), seem to use the words "courtesy" and "conduct" almost interchangeably. The volumes of Library of Congress subject headings provide no explanation for those books indexed under the subject "courtesy," but do provide an explanation for those books indexed under the heading "conduct of life": "Here are entered works on standards of behavior and works containing moral guidance and advice to the individual. ${ }^{6}$ By this definition, Castiglione's Book of the Courtier could 
easily be indexed not only under "courtesy" (which it is), but also under "conduct of life" (which it is not).

Generally, scholars define these terms according to a work's content. For example, in A Checklist of Courtesy Books in the Newberry Library (1942), Virgil Heltzel defines courtesy literature as

any work, or significant part of a work, which sets forth for the gentleman (or gentlewoman) first, the qualities or criteria, inherent or acquired, which he must possess; second, his formation (including his various interests, exercises, recreations, and amusements), and his education; and, third, his conduct. ${ }^{7}$

In Gentlefolk in the Making (1935), John E. Mason also uses the word "conduct" in his definition of "courtesy book" as "a work which discusses the types of human conduct as an expression of class ideals rather than as a subject for metaphysical speculation." 8 W. Lee Ustick, in a 1932 article on advice books for sons, does differentiate between courtesy and conduct, although still on the basis of content: "In general, the book of advice to a son presents not so much those ideals of perfect manhood or of 'institution' elaborated in the Italian courtesy books, as the practical matters which are to be found in books on the conduct of life." "9 Mason and Ustick both agree that "ideals" are embodied in courtesy books, although Mason goes beyond Ustick in allowing for different ideals for different segments of society. In her Bibliography of Courtesy and Conduct Books in Seventeenth-Century England (1937), Gertrude Noyes does not offer'a definition of either type of book. Her index by content contains a heading entitled "Courtesy," but no heading entitled "Conduct." 10

If content is the determining factor, conduct books can be subdivided in a number of ways. For example, a type of book that, like the spiritual conduct book, often draws its evidence and authority from the Bible, is defined and illustrated by C. L. Powell, in English Domestic Relations (1917). Powell defines a domestic conduct book as one that contains "four principal subjects: (1) discussion of the marriage state from religious and secular standpoints, (2) the legal elements involved in contracting matrimony, (3) mutual relations of husband and wife, (4) the government of the family, including housekeeping, the upbringing of children, the management of servants, and general households economics."11 The English Renaissance produced many domestic conduct books, but even with as specific a definition as Powell's, the reader would still find that the books in this category are in some cases catalogued under the heading "courtesy" and in other cases under the heading "conduct of life." 
Jeremy Taylor's Holy Living, which I would characterize as a spiritual conduct book, is identified by P. G. Stanwood, its most recent editor, following earlier work by Helen White and Douglas Bush, as a fruit of one of the branches of devotional literature: "Popular devotional literature, as distinguished from other religious and theological works, included books of prayers, on the one hand, and books of instruction in Christian ethics, on the other. Holy Living belongs to this latter kind of devotional work." 12 Stanwood, however, is not concerned, as I am here, with the definition of a genre by a number of key characteristics.

Courtesy books should be considered a subset of the larger set of conduct books, as the Library of Congress classifications suggest. However, because both courtesy and conduct books contain standards of morality and behavior as well as practical advice, definition by criteria other than content seems more useful. I will define spiritual conduct books on the basis of their audiences, ultimate goals, and principal rhetorical forms, in all of which they are opposed to courtesy books. ${ }^{13}$

Based on a reading of a number of texts, I define an English Reformation spiritual conduct book as one addressed either to a non-court audience or to a universal audience; its ultimate goal is success in the next world, not this one, and its form is drawn from biblical commentary. The texts from which I have drawn this definition are identified variously as conduct manuals, conduct books, and even, in some cases, courtesy books, by scholars such as Heltzel and Noyes, in their bibliographies, and by Mason, Ustick, and Wright. But they can clearly be distinguished from courtesy books and identified with each other in their common concern with the next world and their remaking of the Bible to produce new texts.

The first criterion by which English Reformation spiritual conduct books can be distinguished from both English and continental courtesy books is their intended audiences: courtesy books prescribing the behaviour of princes or courtiers, such as Machiavelli's The Prince, are not intended for mercantile or agrarian workers. Although Noyes does note that the interest in courtesy filtered down through the ranks of society, sprezzatura was not of general interest. Spiritual conduct books are sometimes addressed to specific audiences, and in those cases often to young audiences such as children or apprentices; however, as Arthur Dent declares in The Plaine Mans Path-way to Heauen, the potential audience is universal: "I write to all of all sorts: I speake not to some few of one sort."14 
Like many Reformation texts, conduct books assume an equality before God, although generally not an equality in society. If the ultimate judge of conduct is God, rather than the prince or the courtier, then many standards of conduct are shared by all Protestants. Socioeconomic factors are, at least theoretically, irrelevant to standards of conduct; however, almost all conduct books, of whatever type, acknowledge different socioeconomic ranks because different ranks sometimes demand different conduct in this world. In addition, the Reformation insistence on the duty of Bible reading may have affected literacy rates and certainly created audiences of different types for conduct books. ${ }^{15}$

The first hundred years of the English Reformation produced a wide spectrum of texts related to conduct. Although some, like the translation of Castiglione, ${ }^{16}$ owe their origins to continental courtesy books and focus on ideals or standards for success in this life, others present as their goal for the reader everlasting life in another world. Some texts pay lip service to the latter, but offer advice more suited to the former. Accommodation in standards or practice of conduct is less likely the less the text's author is concerned with success in this world. The ultimate goal of courtesy books is clearly success in this life, even when lip service is paid to spiritual goals. Two influential Italian courtesy books translated into English in the sixteenth century, Baldassarre Castiglione's II Cortegiano, translated by Thomas Hoby as The Courtyer (London, 1561), and Stefano Guazzo's Civil Conversazione, translated by George Pettie and Bartholomew Young as The Ciuile Conuersation of $M$. Stephen Guazzo (London, 1586), are both examples of the concern with behavior in this world. Despite Bembo's neoplatonic celebration of "holy love" in Book 4 of The Courtyer, Castiglione's focus is on the representation of "a good Courtyer, specifying all suche condicions and particuler qualities, as of necessitie must be in hym that deserveth this name." 17

Spiritual conduct books, however, are concerned with success in the next world. Mason points out the disparity between the goals of courtesy books and what I am calling spiritual conduct books, while setting the limits of his own discussion:

A Token for Children (1676) by James Janeway is typical of a large number of works which are more concerned with preparing the child for the world to come than for the world in which we live; therefore, while such works enjoyed a high degree of popularity in their day, a consideration of them would not be to the present purpose. ${ }^{18}$ 
The Protestant abandonment of salvation by merit for salvation by faith/grace might seem to sever the connection between "the world to come" and conduct in this world, but it does not. Even the doctrine of predestination did not discount the conduct of Christians during this life. In The Whole-Armor of God, or The Spiritual Fvrniture which God hath provided to keepe safe euery CHRISTIAN SOVLDIER from all the assaults of Satan (1616), by William Gouge, this life is conceived as a "Christian combate" between the "Defendants, Wee," and the "Challengers or Assaulters," namely the powers of "Wickednesse." 19 Gouge's metaphor, drawn from the Bible, is a commonplace for Catholics as well as Protestants, as Erasmus's Enchiridion illustrates. ${ }^{20}$ But Gouge's use of the metaphor shows that worldly action is significant - for Calvinists because the semblance of godliness in this world is often interpreted as a sign of election, and for other reformers as an aid to faith:

For truth in heart, speech, and carriadge, remember that thou standest alwaies in the presence of God and that thou has to doe with him whether thou art alone, or in company. ... For marke the charge which God himselfe gaue to Abraham, walke before me, and bee vpright. The former part of this charge is a cause of the latter: the latter a fruit and euidence of the former. ${ }^{21}$

As Gouge suggests, the audience and the goal of the work help determine the source of its evidence. In an introduction to a turn of the century reprint of Hoby's translation of Castiglione, Walter Raleigh sees in the book an "almost idolatrous reverence for classical precedent"; 22 courtesy books rely more often on classical authority, spiritual conduct books on religious authority. Even when a classical authority is not cited, courtesy books often allude to classical sources. The English Renaissance translation of Guazzo presents company as "an Antidote [for the 'llness' (solitariness) of one of the dialogue's characters] \& the foundation of life." 23 Classical authors are the origin of this particular valuation of society; ${ }^{24}$ conversely, a thorough reformer would never locate the foundation of anything in this life anywhere but beyond this life. However, some reformers do draw on both biblical and classical authority.

The rhetorical form of Continental courtesy books, which is reproduced in both translated and original English works, is usually the dialogue, probably drawn from Plato. However, the spiritual conduct books with which I am concerned present, explicitly or implicitly, text and commentary, two levels of language. They review and recommend behavior in relation to God, whether that behavior is, by modern terms, secular or not. Although there 
are exceptions (such as Arthur Dent's popular book), most of the conduct books are not dialogues. A brief look through many of them might suggest they are so diverse that they have no single model, but the earliest ones appear to be modeled on the form of biblical commentaries, which accounts for the appearance in all of them of text and commentary.

Although my criteria for distinguishing between courtesy books and spiritual conduct books are pairs of opposed characteristics, I do not mean to suggest that all conduct books published during this period fall into one of two distinct categories. I suggest, instead, a spectrum of works, and one whose range is made even more complicated by the fact that some books addressed to audiences I associate with Reformation spiritual conduct books (such as a mercantile audience) have the goal that I associate with courtesy books (worldly success). In fact, few books fall neatly into one of the two extremes that I have outlined. Few books present a pure set of either "spiritual conduct" or "courtesy" signs. Gertrude Noyes uses the word "amphibious" for books that combine ideals from Christianity and courtesy, ${ }^{25}$ and I will borrow that word to suggest some writers' desire to reconcile the demands of this world and the Christian conception of the next.

While most conduct books are not purely worldly or purely otherworldly, however, the weight of advice in spiritual conduct books is distinctly other-worldly. These books, some of which Louis B. Wright classifies as "Guides to Godliness" 26 are important examples both of how one type of biblical transformation can lead to another and of how class dynamics affect the development of new kinds of texts.

\section{From Biblical Commentary to Spiritual Conduct Book}

The Reformation's demand that all believers read the scriptures led to the production of vernacular Bibles and a consequent explosion of epitomes, harmonies, paraphrases, and commentaries. Obviously, biblical commentary is not a Reformation phenomenon. Jewish and Christian scholars have produced commentary that can be seen to begin with the psalms in the Old Testament and the epistles in the New Testament, or even with Genesis in the Old Testament and the gospels in the New Testament - in the beginning, so to speak. The books of the Bible themselves are in some sense commentaries. Biblical commentary also reflects classical commentaries on other texts, classical ways of reading. Texts have been and still are constantly remade by the critical impulse. However, the new audience of the Reformation, the audience of all Protestants, demanded by its composition 
both more and different commentaries, because the new audience, although universal, was stratified and therefore required different commentaries for different strata. In turn, some spiritual conduct books doubtless helped maintain the hierarchical society by placing more importance on the life to come than on this life. In The Protestant Ethic and the Spirit of Capitalism (1930), for example, Max Weber argues that religious asceticism of the kind prescribed in spiritual conduct books provided "the comforting assurance that the unequal distribution of the goods of this world was a special dispensation of Divine Providence, which in these differences, as in particular grace, pursued secret ends unknown to men."27

Commentary by its nature and in its different Reformation varieties can be linked to prescriptions of thought and behavior and thus to the genre of conduct. One early example is an anonymous work entitled The Summe of the Holye Scripture (Tr. Simon Fish 1529; prohibited in England in 1530) that, while neither commentary nor conduct book, is related to both. The early date of this work, before Henry VIII divorced the Church of England from the Roman Catholic Church (1534), explains its prohibition, for one of its purposes is to condemn the abuses of the monastic orders. (Another reason for its prohibition may have been statements that would have upset the higher ranks of the social order, such as "He that is riche and liveth of his rentes ought first to knowe that he may not vse nor spend his goodes as he will: for he is but a kepar and a dispensatour therof." 28 ) More relevant to this discussion, The Summe first presents a summary of the tenets of the Bible as interpreted by early Protestants and then offers a series of chapters that outline conduct, according to the Bible, for members of various segments of society, from parents and children to rulers. Like later conduct books, The Summe presents biblical references to support its prescriptions of conduct.

An early spiritual conduct book that more clearly shows the connection between biblical commentary and the spiritual conduct book is Thomas Becon's The Gouernaunce of Vertue, teaching of faithful Christians, how they oughte dayly to lead their lyfe (first published 1538; 10 editions are listed in Pollard and Redgrave, Short Title Catalogue, 1475-1640). The title clearly states the book will provide directions for conduct for an audience composed of "faithful Christians"; indeed, the first fifteen or so pages of the book present prayers for various times of the day, interspersed with precise directions for daily activities (the first page begins "How a man shuld behaue him self in the morning when he ryseth"). However, more than 400 pages of a book of less than 500 pages are devoted to a list subsumed under the title 
"Remedies against all kyndes of temptacions." 29 These "remedies" are actually quotations and paraphrases from and commentary on the Bible, organized, in response to each successive "temptacion," under headings of "Sentences" and "Examples" from the Old or New Testament. The Bible is envisioned as a shield with which to "enarme thy self against [Satan]"30 and his temptations. But Becon has reorganized and rearranged the verses of the Bible, choosing, as the preacher Nicholas Byfield will later suggest, a number of passages appropriate to each subject.

Becon's book is thus both commentary and conduct book; it is the best example I have found of how the two forms are related. In fact, it was apparently intended to function also as another "good book." The entry on Becon in the Dictionary of National Biography quotes him as writing later that he wrote this book, "in the bloody, boisterous, burning time, when the reading of the holy Bible, the word of our soul's health, was forbidden the poor lay people." 31 Apparently, the audience identified by the book's title is broader than the author's actual intended audience, which excludes those with connections and resources like Becon's. Although the biblical verses and commentary would offer "the poor lay people" access to Becon's version of the Bible, the commentary on the verses (presented in editions after 1578 in a different typeface from the verses) does not explicitly prescribe conduct, despite the claim of the book's title. However, Becon's choice of passages and his comments on them do constitute a commentary, and a starting point for the exploration of variations on commentary in these English Reformation conduct books.

A text that represents a further step in the development of the English Reformation spiritual conduct book is The Whole-Armour of God by William Gouge mentioned above. Gouge's title is reminiscent of the introductions to the temptations for which Becon offers remedies; here's one example:

\section{Against the heresie of such as deny Iesu \\ Christ to be God.}

If Satan at any time moueth the to doubt of the Godhead of Christe as though he were onely man and not God, a creature or a thing made and not the Creator, and maker of all thinges, then arme thy self against him with these Scriptures. ${ }^{32}$

Both writers use the commonplace metaphor of "arming" the Christian; Gouge, however, goes much further with the metaphor than Becon, and yet as he does so he both limits the focus of his biblical commentary and makes more explicit how standards of conduct are generated from the Bible. Gouge's book is a commentary on Ephesians 6.10-20, which itself presents 
an extended analogy between armor and spiritual protections. In his exegesis of each piece of armor, Gouge translates metaphor into conduct, and conduct is itself presented as a sign of faith or grace.

In Gouge's exegesis of Ephesians 6.17, "And the sword of the Spirit, which is the Word of God," he provides instructions for reading the Bible (the word, and therefore the sword) and for extending biblical interpretation to action. In one example, Gouge instructs readers that the "sword" signifies the need for Christians to take offensive action against Satan (in contrast to the defensive posture suggested by the other pieces of armor in Paul's analogy). His commentary translates the metaphorical into action, and because of the disparities between Christians in this world, Gouge provides explicit directions for different audience members:

Here is a good direction for Magistrates that haue a charge ouer people committed vnto them, that they content not themselues with defending such as are vnder their gouernment from idolators, heretiques, atheists, worldlings, and the like enemies, but that they cut off and destroy those dangerous and mischievous enemies.

Heere is a direction also for ministers, they must not onely teach the truth, instruct in good manners, incourage the vpright, but also refute errors, cut downe sin, \& indeauour to destroy whatsoeuer maketh against the glorious Gospel of Christ.

As for priuate persons euery one hath charge ouer his owne soule, for their owne soules safety they must resist Satan, oppose against the world, subdue their flesh, strike and fight: it is a foolish pitty to spare the enemy, and destroy a mans self. ${ }^{33}$

Gouge's directions show that correct application of the word requires both faith and knowledge, as well as that faith must be evidenced by conduct.

Application of the word is inextricably associated with reading the word. Instructions for reading the Bible are one of the few subjects on which different Protestant sects agreed in Reformation England. Gouge identifies seven "diuers profitable means" for "finding out the true sense of scripture": "Vnderstanding of the originall tongues," "Skill in the [rhetorical] arts," "Knowledge of the analogie offaith," "Observation of the scope of that place which is interpreted," "Comparing one place with another," "Prayer," and "Faith and obedience to Gods word so farre as it is made knownen. ${ }^{34}$ Approximately 50 years later, John Milton's list of the "requisites for public interpretation of Scripture" in On Christian Doctrine include all of those means listed by Gouge, except prayer, which is probably taken for granted. ${ }^{35}$ 
Both Gouge and Milton acknowledge that those without training in ancient languages also have the right and the duty to interpret the Bible for themselves. In The Art of Prophesying, the widely read theologian William Perkins states: "The supreme and absolute meane of interpretation, is the Scripture it selfe... . The means subordinated to the Scripture, are three; the analogy of faith, the circumstances of the place propounded, and the comparing of places together." 36

The importance of comparing one place with another (the comparison of texts) is commonly accepted; Nicholas Byfield's "little paper book" is a concrete application of the principle of comparison of texts. This characteristic of hermeneutic methodology and its use in exegesis and, therefore, biblical commentaries, may help explain the plenitude and the variety of similes in English Reformation spiritual conduct books. The similes sometimes constitute both commentary and direction for conduct; they suggest the foundation of commentary on the figure of similitude and illustrate the variety of biblical remaking generated by an application of scripture to conduct.

\section{Variations in Remaking the Bible}

Authors of spiritual conduct books remade the Bible in ways that can themselves be considered commentary. Among the variations discussed below are a spiritual conduct book by Dorothy Leigh that reproduces or copies one type of book in the Bible (the gospels, in this case) and a spiritual conduct book by Abraham Jackson that collects and comments on parallel passages (a harmony). Some books mix the concerns of the courtesy book with those of the spiritual conduct book. Besides differences in form, spiritual conduct books reveal differences in how the emphasis on life in the next world affects prescriptions for conduct in this one. Jesus's statement "If a man love me, he will keep my words: and my Father will love him, and we will come unto him..." (John 14:23) can be used to support different claims about how Protestantism should be practiced. Some words in the New Testament are potentially subversive of the English Renaissance power structure; for example, Christopher Hill points out that the word "tyrant" appears numerous times in the Geneva Bible, but not a single time in authorized King James version. ${ }^{37}$ Others can be used to support the belief that the monarch is God's hand on earth, with all of the implications of that belief. Some spiritual conduct books may have been intended to support the 
socioeconomic status quo, while others may have been intentionally subversive.

One of the most widely read English devotional books of the seventeenth century is Lewis Bayly's The Practice of Pietie (3rd. ed. 1613; date of first edition unknown). It is one of two books named by John Bunyan in his spiritual autobiography, Grace Abounding to the Chief of Sinners, as instruments that aroused Bunyan's interest in religion. ${ }^{38}$ Bayly's book covers conduct of thought and action, prayer and observance. The title page of his book, as well as its subtitle (Directing a Christian how to walke that he may please God), suggest that before God conduct subsumes both thought and action on every subject. At the top of the title page of the 1613 edition is a kneeling man; behind him on a table, on which is written "Read," is an open book, presumably the Bible, while before him is an altar, with "Pray" written on its side, topped with a burning and broken heart. The praying man, the table, and the altar are atop a platform raised on three steps labeled Faith, Hope, and Charity. This graphic presentation and others (the title page is crowded with woodblock prints) indicate that devotion and conduct cannot be separated. Bayly presents the intent of his book as being to produce "an vnfained Practitioner of Pietie." 39 Both spiritual and physical conduct in this world must be shaped to achieve that end.

Bayly's directions for reading the Bible help to clarify how the word is translated into conduct. His first suggestion of what subjects for meditation a practitioner of piety may find in scripture is "good counsels or exhortations to good workes, and to holy life." 40 Bayly directs that all actions be scrutinized in relation to God's will. Like Gouge, he offers special directions for readers in particular occupations and for those who have authority over others. However, when Bayly uses the word "Master," he refers to God; Bayly is not a member of a fringe sect, but he was a staunch opponent of the ecclesiastical hierarchy of the Church of England. For him, earthly authority is temporary.

Also like Gouge, Bayly insists on the importance of works despite the primacy of faith. In the midst of "Meditations of the misery, of the body and soule in death," a vivid docudrama complete with lamentations within and hellhounds come from without, Bayly insists that sins cannot be forgotten: "they flow faster into thy remembrance, and they will not be put away, but cry vnto thee, Wee are thy workes, and we will follow thee. ${ }^{41}$

Bayly cautions his reader, "read not these Chapters as matters of Historicall discourse: but as if they were so many Letters or Epistles sent 
downe from God out of Heauen vnto thee. ..."42 This insistence on collapsing the temporal distance between God's word and human action in seventeenth-century England is, of course, typical of a culture that read its own history, national and personal, typologically. The chapters in the quotation are chapters of the Bible, but another writer of a spiritual conduct book goes so far as to suggest that her work is another gospel, a new epistle sent out into the world and up to heaven.

Dorothy Leigh, the author of The Mothers Blessing, or The Godly Counsaile of a Gentlewoman not long since deceased, left behind her for her children (1616) - a book at least ostensibly written for her three sons, whose father had already died - not only wants her sons to be good Christians; she writes to them in hopes "that then you would remember to write a booke vnto your children, of the right and true way to happinesse, which may remain with them and theirs for euer." 43 Leigh writes: "It may bee you maruell my Sonnes, why I write so much of Christ. Maruell not why I write, for I wonder, that euery one which hath heard of him, doeth not write what Christ hath done for vs." 44 Leigh believes that every Christian should write her or his own book, a personal gospel; the inspiration may come from John 21.25, which she paraphrases: "If all things which Christ did were written, the world would not containe the Bookes." 45 Leigh is writing such a book, and she wants her sons to write such books; we can imagine as many books "of the right and true way to happinesse" as there are Christians, all of which would be personal gospels.

Just as the notion of Leigh's book as one of many "good bookes, written of the mercies of God in Christ" 46 collapses the distinction between the Bible and her book, Leigh repeatedly constructs similes that collapse the gulf of time between the incarnation and her life. In one such example, she constructs a typological connection between her sons and the Israelites wandering in Sinai:

For as the children of Israel must needs starue, except they gath'red [manna] euery day in the wildernesse and fed of it, so must your soules, except you gather the spiritual Manna out of the word euery day, and feed of it continually, for as they by this Manna comforted their harts, strengthened their bodies, and preserued their liues; so by this heavenly Word of God, you shall comfort your soules, make them strong in Faith, and grow in true godlinesse, and finally preserue them with great joy, to euerlasting life, through Faith in Christ. ... ${ }^{47}$

Leigh occasionally even goes so far as to put words in the mouth of her Christ, as when, in the middle of a long passage about the devil's tricks to lure people to hell, she writes: 
I tell them now, if they come once in hell with the diuel, they shall neuer come in heauen with Christ; for he is iust, and will not meddle with the servants of another. But if anie see his filthie and base waies, and consider the miserable and wretched estate it will bring him vnto, and then turne to me (saith Christ) and defie the Diuell and all his workes, and serue me, I will saue him; for I am a Sauior, and that is my name, and my glorie. ... 48

This passage continues in the voice of Christ for more than three pages; this is the gospel according to Dorothy Leigh. Her willingness to write her own gospel is one sign that despite her own conventional comments on gender relations, Leigh breaks with tradition in presenting anyone - male or female, rich or poor - as a potential gospel author. She writes to her sons "Maruell not why I write," because she recognizes that for her to write as she does is a marvel.

Like Leigh, Abraham Jackson, a clergyman, produced a spiritual conduct book addressed to young people (apprentices in his case) that constructs both typological similes and a specialized or personalized version of the Bible. Like Thomas Becon, Jackson in The Pious Prentice (1640) collects biblical passages, related to service in this case, and presents to apprentices "such precepts, promises, threatnings and examples as are found in Gods booke touching servants." 49 His book is a "microbiblion" for apprentices.

The ordering of biblical verses in Jackson's table suggests that the order of books in the Bible is an important organizing principle. That may be an obvious statement, but there is nothing to prevent remakers of the Bible from rearranging the order of verses; in some cases, a rearrangement would produce a more logical progression. Perhaps the movement from promise in the Old Testament to fulfillment in the New Testament is significant because the order creates commentary in the sense that a believer sees the potential for fulfillment of the promise to himself. For example, the first promise in one section of Jackson's table is from Proverbs 13.33: "The kings favour is towards a wise servant"; grammatically, the sentence is not a promise, and only through interpretation of the "king" as "God" and of this general sentence as having particular application — only through exegesis — is the sentence interpretable as a promise to be fulfilled through the incarnation.

I classify Jackson's book as a spiritual conduct book in part because his advice to apprentices is based on the belief that obedience to God is more important than obedience to a master if the master commands the apprentice to "doe a wicked or sinfull thing." 50 However, the apprentice must be certain that the command is wrong and, even then, Jackson insists that "though God free you from actuall obedience of your Master in this case, yet hee frees 
you not from reverence in the manner of your refusall to obey." 51 The use of the Bible to justify the power of masters over servants is an ideological operation beyond the scope of my argument although clearly one popular with those concerned with preserving the hierarchical status quo. Jackson has little trouble reconciling the demands of this world with the demands of religion. However, other conduct books do present an irreconcilable combination of worldly and spiritual goals and of classical and biblical evidence. These books are interesting in part because they attempt to reconcile different standards of conduct that are finally irreconcilable.

Two "amphibious" books, to use again Gertrude Noyes's term for books that combine Christian and classical ideals, of different sorts are William Martyn's Youths Instructions (1612) and William Scott's An Essay of drapery: or, The Compleate Citizen. Trading Iustly, Pleasingly, Profitably (1635). Both Martyn and Scott combine standards of courteous and spiritual conduct, although Scott is trying to reconcile not the conduct of the ideal gentleman and the ideal Christian, as Martyn is, but the conduct of the ideal Christian and the ideal citizen-tradesman. At times, Scott's dedication to spiritual goals is remarkably transparent. He counsels citizens (presumably his fellow drapers in particular): "He whom no busines should put out of our mindes, is in Heaven ... and when thou hast thus found him, hee will take thee up to Heaven to raigne with him there." 53 On the next page, however, Scott explains that "to minde the affaires of the soule, is the way to prevent distraction," so the reader cannot be sure if God should come first for God's sake or for the sake of a settlement of spiritual affairs that will prevent distraction in the shop. At times, Scott also counsels citizen-tradesmen to take the Aristotelian middle ground, and his motives are worldly, as in his advice that "There is as much injustice in selling commodities too cheap, as too deere...."54 The end of Scott's book provides the most amusing instance of his attempt to reconcile the goals of profit and salvation:

". . . so for a conclusion, I propound the Words of our Saviour, Negotiamini, donec, venero, Trade while I come: Let my Citizen remember his comming, and so let him trade now, as he may be able to give an account of his trading hereafter." 55 The source of the quotation is probably Luke 19:13, the relevant part of which is translated in the King James Bible as "Occupy till I come." Ironically, Scott seems to take a parable and read its allegory as if it were literal.

Historian William Martyn's Youths Instructions, dedicated to one of the author's sons, Nicholas, then a student at Oxford, combines a claim that 
spiritual concerns are more important than secular ones, the same claim made by Scott, with standards and precepts from classical authors, such as the following, clearly Aristotelian, statement: "In summe they do all best agree when they say, that virtue consisteth in action, and that the meditation thereof without practise, is an vnstringed instrument, whereon no man plaieth." 56 Martyn also occasionally offers advice that seems to have been derived from Machiavelli. Martyn's divided perspective is readable in his similes, which are both plentiful and astonishing in their layers of similitude, as this example suggests:

As water (being powred into a vessell) doth expell the Ayre: and as the children of Israel did the heathen Nations out of the Countries and Prouinces of the land of Canaan: it [sin] suddenly bereaueth a man of all his former practised vertues, as a little Axe (by few strokes) cutteth downe; or as a whirlewind (with one furious blast) ouerturneth, the greatest and tallest trees, which for many yeers haue bin growing to their perfect strength and greatnesse. ${ }^{57}$

In this sentence, the power of sin is sandwiched between (and is a term in) four similes; sin is compared to water, to the children of Israel, to an axe, and to a whirlwind. The mixture of natural, and perhaps quasi-scientific, comparisons with the biblical comparison could stand as a figure for Martyn's mixture of the pious and the worldly; the comparison of the children of Israel's expulsion of heathens from Canaan to sin tossing virtues out of a man is baffling. Unlike Scott, Martyn does not seem to grasp the potential irreconcilability of the standards of conduct he offers. Youths Instructions is both disorganized and yet packed with figures of speech that merge biblical and classical sources as if Martyn is unconsciously creating a hypothetical precedent text that is an anthology of the Bible and classical authors.

Most of these conduct books (all of them with the exception of the courtesy books by Castiglione and Guazzo) have received little critical attention. One reason may be the differences between these texts and courtesy books; spiritual works often are not considered part of the same canon as secular works that derive their authority and their rhetorical forms from the classical tradition. Although it is possible to argue that English Reformation spiritual conduct books are derived from classical sources, but far more distantly than are courtesy books, we can learn more about the development of all kinds of conduct books if we acknowledge that different traditions feed into that development. 
The spiritual conduct books discussed here are important in part for the insight they provide into how English Protestants generated standards for conduct. As Christopher Hill points out in The English Bible and the Seventeenth-Century Revolution (1993), the Bible was for most English at that time, "the unique source of divine wisdom on all subjects," 58 even subjects that modern readers would not consider related to religion. Thus, these conduct books point out yet once more the centrality of the Bible/the word for English Reformation Protestants. They also illuminate one of the ways in which the popular dissemination of the Bible shaped many of the texts produced over the course of the English Reformation.

Some of these books were hugely popular. Lewis Bayly's The Practice of Pietie may have been one of the most popular texts of the century, outside of those texts authorized for printing by the English government; according to the Short Title Catalogs (1475-1640 and 1641-1700), it went through more than 100 printings in less than 100 years. This popularity is a sign of the importance of spirituality in this period. More important, the number of these texts, only a few of which I have introduced here, indicates that many writers and many readers were eager to set biblical precepts and patterns in new configurations.

Finally, spiritual conduct books intersect with modern interests on two seemingly disparate subjects: the nature of the text and the nature of class. Spiritual conduct books might be considered prehistoric (to the history of the computer, that is) hypertexts. Repeated references to various biblical passages, as well as to other textual authorities, suggest the same image of a web of documents. During the English Reformation, however, the center of the web was clear; it was the Bible. Becoming less clear even more quickly than the Bible's centrality was the relation between the authority of the Bible's text and the authority of the government, secular and ecclesiastical, that represented itself as acting under divine authority. The English Civil War may be pinpointed, inaccurately but usefully, as the time when the Bible's authority was still widely acceptable, but its direct link to governmental authority had been severed. Christopher Hill argues that "the political revolution and its consequences shattered the universal acceptance of the bible as an infallible text whose pronouncements were to be followed implicitly." 59 The reformers of England were convinced that they were acting on biblical authority but that their monarch was not. This change in class relations may help explain some of the differences among the period's 
spiritual conduct books, as well as the confusion of beliefs some of them present. In this case, genre and class seem to be inextricably intertwined.

Northwestern State University of Louisiana

\section{Notes}

1. I wish to thank the members of my research group - Benay Blend, Karen Cole, Jean D'Amato, and Susan Newton - for their responses to earlier versions of this article.

2. John Bunyan, Pilgrim's Progress, ed. N. H. Keeble (Oxford: Oxford University Press, 1984), p. xiii.

3. Part of Wastell's book is a translation of a Latin summary by John Shaw (1621), that is in turn based on a synopsis by John Shepery (1586).

4. New Cambridge Bibliography of English Literature, 5 vols. Ed. George Watson (Cambridge: Cambridge University Press, 1974-77), vol. I, p. 1843.

5. Nicholas Byfield, Directions for the Private Reading of the Scriptures, 2nd. ed. (London, 1618), $\mathrm{A} 10^{\mathrm{r}-\mathrm{v}}$.

6. Library of Congress Subject Headings, 17th ed., 4 vols. (Washington: Library of Congress, 1994), vol. 1, p. 1129.

7. Virgil B. Heltzel, A Checklist of Courtesy Books in the Newberry Library (Chicago: Newberry Library, 1942), pp. vii-viii (italics are mine).

8. John E. Mason, Gentlefolk in the Making: Studies in the History of English Courtesy Literature and Related Topics from 1531-1774 (Philadelphia: University of Pennsylvania Press, 1935), p. 291.

9. W. Lee Ustick, "Advice to a Son: A Type of Seventeenth-Century Conduct Books Book," Studies in Philology, 29 (1932), p. 441.

10. Gertrude E. Noyes, Bibliography of Courtesy and Conduct Books in Seveteenth-Century England (New Haven, Tuttle, Morehouse \& Taylor, 1937), index.

11. Chilton Latham Powell, English Domestic Relations, 1487-1653: A Study of Matrimony and Family Law in Theory and Practice as Revealed by the Literature, Law and History of the Period (New York: Columbia University Press, 1917), pp. 101-2.

12. P. G. Stanwood, Introduction to Holy Living and Holy Dying, by Jeremy Taylor, 2 vols.(Oxford: Clarendon Press, 1989), vol. I, p. xxxiv.

13. Heltzel's definition includes a reference to audience. Mason's use of the term "ideals" reflects his acknowledgment of different audiences, but his aim, in his own words, is to "outline the picture of the English gentleman and gentlewoman as usually portrayed in didactic treatises between the time of Elyot and that of Chesterfield ..." (Op. cit., p. 3); therefore, he pays only glancing attentions to three of the books I discuss here.

14. Arthur Dent, The Plaine Mans Path-Way to Heaven (London, 1601; rpt. Amsterdam: Theatrum Orbis Terrarum, 1974), p. A4r.

15. In Literacy and the Social Order, David Cressy argues that reformers' calls for universal education did not lead to dramatic changes in either education or literacy rates, and that 
literacy in Tudor and Stuart England is more strongly linked to occupational demands for that skill than to other factors (David Cressy. Literacy and the Social Order: Reading and Writing in Tudor and Stuart England [Cambridge: Cambridge University Press, 1980]). However, Cressy also writes: "By the end of the Stuart period the English had achieved a level of literacy unknown in the past and unmatched elsewhere in early modern Europe" (p. 176).

16. Baldassarre Castiglione, The Book of the Courtier, tr. Thomas Hoby, Tudor Translations, First Series (1900; rpt. New York: AMS Press, 1961).

17. Loc. cit., p. 42.

18. John E. Mason, Op. cit., pp. 76-77.

19. William Gouge, The Whole-Armor of God, or the Spiritval Fvrniture which God hath provided to keepe safe euery CHRISTIAN SOVLDIER from all assaults of Satan (London, 1616), p. A7r.

20. Erasmus, The Enchiridion of Erasmus, tr. Raymond Himelick (Gloucester, MA: Peter Smith, 1970), p. 38.

21. Loc. cit., pp. 135-36.

22. Baldassarre Castiglione, Op. cit., p. 9.

23. Stefano Guazzo, Op. cit., p. $3^{\mathrm{v}}$.

24. For example, see the representation of one fundamental quality of man as a "natural fraternity," in Cicero, De Officiis, tr. Walter Miller, Loeb Classical Library (Cambridge, MA: Harvard University Press, 1990), p. 53 (1.xvi.50).

25. Gertrude E. Noyes, Op. cit., p. 8.

26. Louis B. Wright, Middle-Class Culture in Elizabethan England (Ithaca: Cornell University Press, 1935; rpt. 1958), p. 228.

27. Max Weber, The Protestant Ethic and the Spirit of Capitalism, tr. Talcott Parsons (1930; rpt. New York: Charles Scribner's Sons, 1958), p. 177.

28. The Summe of the Holye Scripture and Ordinarye of the Christen Teachyng the True Christen Faithe by which We Be All Iustified. And of the Vertue of Baptesme after the Teaching of the Gospell and of the Apostles with an Informacyon Howe All Estate Shulde Lyve Accordynge to the Gospell, tr. Simon Fish (Antwerp, 1529), p. N2v.

29. Thomas Becon, The Gouernaunce of Vertue, teaching of faithful Christians, how they oughte dayly to leade their lyfe, \& frutefully to spende their tyme, vnto the glorye of God and the health of their own Soules, 3rd ed. (London, 1578), p. 16.

30. Loc. cit., p. 28.

31. Quoted in Dictionary of National Biography, eds. Leslie Stephens \& Sidney Lee, 64 vols. (London: Smith, Elder, \& Co., 1885-1903), vol. 4, p. 93.

32. William Gouge, Op. cit., p. $11^{\mathrm{v}}$.

33. Loc. cit., pp. 306, 307, 307.

34. Loc. cit., pp. 309, 310, 311.

35. John Milton. On Christian Doctrine, in The Works of John Milton, ed. Frank Allen Patterson, 18 vols. (New York: Columbia University Press, 1931-38), vol. 14, p. 263. 
36. William Perkins, The Art of Prophesying or, A Treatise Concerning the sacred and onely true manner and methode of preaching, in The Works of that Famovs and Worthy Minister of Christ in the Vniversitie of Cambridge, tr. Thomas Tuke (London, 1631), vol. 2, p. 651.

37. Christopher Hill, The English Bible and the Seventeenth-Century Revolution (London, Penguin, 1994), p. 59.

38. John Bunyan, Grace Abounding to the Chief of Sinners, ed. W. R. Owens (1666; rpt. London: Penguin, 1987), pp. 9-10.

39. Lewis Bayly, The Practise of Pietie: Directing a Christian How to Walke That He May Please God, 3rd ed. (London, 1613), p. 1.

40. Loc. cit., p. 311.

41. Loc. cit., p. 98, misnumbered as 88 .

42. Loc. cit., p. 312.

43. Dorothy Leigh, The Mothers Blessing, or The Godly Counsaile of a Gentlewoman not long since deceased, left behind her for her children: Containing many good exhortations, and godly admonitions profitable for all Parents to leave as Legacy to their children, but especially for those, who by reason of their young yeeres stand most in need of Instruction (London, 1616), p. 16.

44. Loc. cit., p. 90.

45. Loc. cit., pp. 92-93.

46. Loc. cit., p. 94.

47. Loc. cit., pp. 5-6.

48. Loc. cit., p. 187.

49. Abraham Jackson, The Pious Prentice, or, The Prentices Piety (London, 1640) pp. 4-5.

50. Loc. cit., p. 110.

51. Loc. cit., p. 112.

52. See, for example, A Diamonde Most Precious Instructing all Maysters and Seruauntes, how they ought to leade their lyues (1577).

53. William Scott, An Essay of Drapery: or, The Compleate Citizen. Trading Iustly, Pleasingly, Profitably (London, 1635), p. 83.

54. Loc. cit., p. 47.

55. Loc. cit., pp. 168-69.

56. William Martyn. Youths Instruction. Wherein are Briefly Set Forth All Necessary Rules for the Ordering of a Mans Whole Life (London, 1612), p. 18, misnumbered as 10.

57. Loc. cit., pp. 7-8.

58. Christopher Hill. Op. cit., p. 18.

59. Loc. cit., p. 39. 